\title{
Strategies to Implement Independent Learning Programs: A Reflective Study on Ministerial Programs
}

\author{
Harmanto Harmanto ${ }^{1}$ Bambang Yulianto ${ }^{2}$ Muhammad Sholeh ${ }^{3}$ Hasan Subekti ${ }^{4}$
}

\author{
Sueb Sueb ${ }^{5, *}$ \\ ${ }^{1}$ Civics Education Program, Universitas Negeri Surabaya, Indonesia \\ ${ }^{2}$ Indonesian Language and Literature Education Program, Universitas Negeri Surabaya, Indonesia \\ ${ }^{3}$ Science Education Program, Universitas Negeri Surabaya, Indonesia \\ ${ }^{4}$ Educational Management Program, Universitas Negeri Surabaya, Indonesia \\ ${ }^{5}$ English Langauge Education Program, Universitas Negeri Surabaya, Indonesia \\ *Corresponding author.Email: sueb@unesa.ac.id
}

\begin{abstract}
The essence of Independent Learning (MB-KM) programs proposed by the Ministry of Education and Culture is to explore the potential of university learners and students in innovating and improving the quality of learning independently beyond the main study programs. In line with MB-KM policies, higher education should implement strategic policies to transform education through harmonization of Higher Education Main Performance Indicators (IKU). This qualitative reflective study collected the data through surveys and focus group discussions with students and relevant stakeholders. The results of this study show that several activities that accommodate the implementation of MB-KM include teaching at schools, research and internships, student exchanges/mobility, independent studies and certified internships. Several issues emerged in the implementation of the programs, namely the activities run at the same time so that the MB-KM system/account managed by the Ministry of Education and Culture has not been able to accommodate registered participants. As a result, the list of students is not stable as well as the lecturers involved; the implementation of on-site and online programs during the partial social restrictions due to pandemic leads to mutual jealousy among students; concerns from universities whose burdens to accommodate the programs. Lastly, the need for synchronization of MB-KM policies between public and private universities, especially in relation to fund management and credit transfer and conversion policies.
\end{abstract}

Keywords: Independent learning, Strategic policies, MB-KM Curriculum.

\section{INTRODUCTION}

This study is intended to overview the Independent Learning program as the implementation of the Independent Learning - Freedom Campus (MB-KM) Curriculum by the Ministry of Education and Culture and how the university's strategy to accommodate the Independent Learning programs, especially proposed by the government. The Ministry of Education and Culture launched the MB-KM Curriculum in 2019, including the Independent Learning program, one of which promotes one major trend of granting the students the right to study and/or take academic activities outside the main study program (home campus). The policy has been followed by several academic programs to implement the MB-KM Curriculum.
One of the most recent and popular programs is Kampus Mengajar -literally translated as Campus Teaching or Campus Goes to Schools. The program was previously preceded by a similar pilot program which was implemented in 2020 which is considered positive from the relevant parties. The principle of this program is how campuses take stance by sending the students to the schools conducting educational assistantship to teachers, adaptation of information and technology to the schools, and revitalization of the school administration for schools affected by the pandemic [1]. Campus Teaching program is part of the Independent Learning program which involves students through activities outside of the classical activities at the main study program. This program is expected to produce graduates who are ready to champion the increasingly complex 
challenges of life in the $21^{\text {st }}$ century [2] especially the education sector and respond to the educational needs of the Industrial Revolution Era 4.0 [3].

Campus Teaching is one of the examples. The essence of Independent Learning is to explore the potential of the students in innovating and improving the quality of learning experience independently [3], even outside the campus or main study program. In line with the policies under the MB-KM Curriculum, universities are challenged to transform their academic policies and strategies through harmonization of the Primary Indicators of Performance (IKU) of higher education [4]. There are several other Freedom Campus programs from the Ministry of Education and Culture, that not only involve students but also involve study programs, namely Center of Excellence (CEO) program, Curriculum Partnerships Assistantship Implementation of MB-KM.

Grant for the

The presence of IKU is fundamental to accelerate the implementation of MB-KM programs at the higher education [4]. One of the targets of the primary indicators is to improve the quality of curriculum and learning. In this context, universities have to ensure that academic activities are carried out in accordance with the ideals of the nation, namely the intellectual life of the nation [5]. This is in line with the theme of the growth strategy recommended for the development of higher education towards internationalization [6]. Thus, higher education institutions are required to be able to integrate various main issues of sustainable development into learning.

However, until the early 2021 (two years after the government issued the policy of Independent Learning), there has been no study exploring the strategy of managing the Independent Learning in higher education, even though this is a central government program, in this case from the Ministry of Education and Culture. This research intends to fill the gaps in the study of research recommendations regarding the evaluation of the implementation of MB-KM curriculum in universities. However, studies on the development of the MB-KM curriculum have been carried out [7] and how to implement Independent Learning in higher education has been carried out at the policy level not at the implementation and evaluation strategy. In an effort to design strategic policies to implement these Independent Learning programs, universities should have mapped the strengths, weaknesses, potentials, and challenges upon the program [8].

Based on the explanation above, the purpose of this strategic policy research is to map the MBKM Curriculum management strategies, especially Independent Learning programs from the Ministry of Education and Culture. Thus, various good strategies will be obtained - best practice for managing the MBKM programs at universities in general in Indonesia. In detail, these objectives are expected to explain several programs from the government related to the implementation of MB-KM programs, including the management strategies, and reflection on the challenges and opportunities of the strategies that have been implemented on the existing programs.

\section{METHODS}

This is a descriptive study on particular programs and policies in regards with the implementation of Independent Learning programs. The research involved undergraduate (Bachelor's Degree) and Diploma-IV study programs at the State University of Surabaya (Unesa). The relevance of Unesa as a research subject is as one of the top-tier teaching universities in Indonesia which is believed to be capable of adapting the emerging trends of educational policies and curriculum.

The data in this study were in the form of archives or documentation related to the target of improving the organizational strategies of Independent Learning programs, of which are the programs specifically from the Ministry of Education and Culture, including the Campus Teaching, Center of Excellence , and Curriculum Partnerships Assistance Grant for MB-KM Curriculum. Some of the data materials needed include the partnership documents with relevant partners, curriculum of study programs, other relevant procedural documents, and strategies that are being implemented. Due to the roles and access, researchers acted as the main actors and instruments at the same time to analyse the document. It is stated that the researcher becomes an instrument in semi-structured or unstructured qualitative research, the unique characteristics of the researcher have the potential to influence the collection of empirical material [12].

The data analysis was conducted qualitatively by using the software of NVIVO 12 for Window, referring to the data analysis step from Jamieson [13], with data analysis steps of: (1) data preparation, namely the conversion of written text or import data into the form used; (2) immersion in the data, namely immersion of textual data through repeated reading activities; (3) coding was marking transcripts and analyzing data to find meaning; (4) generation of theme, namely grouping code into themes, and (5) abstraction, namely synthesizing to produce explanations [13]. The data in the form of numbers were analyzed in the form of percentages and the trend of the data was represented. The results of this quantitative data were used as the basis for conducting focus-group discussion with relevant stakeholders at the university which included the Vice Dean for Academic Affairs, Institute for Learning and Professional Development through the Center for Learning 
Development, the Head of the study programs, and the Head of Center for MB-KM along with the divisions.

\section{FINDINGS AND DISCUSSION}

In this section, some university's strategies and policies are presented in regards with the implementation of the Independent Learning programs originating from the Ministry of Education and Culture. At the end of this section, general reflection on some of the constraints and opportunities for further program development are described.

\subsection{Independent Learning Programs from Ministry of Education and Culture}

In implementing the MB-KM Curriculum, programs are either from universities (independent programs) and programs launched by the government through the relevant ministries that have launched several programs under the theme of Independent Learning, both for students and the respective study programs.

\subsubsection{Campus Goes to School}

"Kampus Mengajar", literally translated as Campus Teaching (Campus Goes to School) is a teaching assistantship at schools as part of the Freedom Campus program. The purpose of the program is to provide students to conduct teaching assistantship as part of strengthening literacy and numeracy learning at the schools. In addition, the program supports the schools during the pandemic, especially for elementary schools in the remote area. The implementation of this program is supported by Indonesia Endowment Fund for Education (LPDP).

This program was initiated by a pilot program in 2020 to measure the extent of the enthusiasts and their management. This program emphasizes learning assistantship to the teachers, the adaptation of information and technology in learning activities, and that raise the issue of literacy and numeracy education in schools. The success of the $1^{\text {st }}$ batch of Campus Teaching in 2021 prompted the Directorate General of Higher Education (Ditjen Dikti) to open registration for the $2^{\text {nd }}$ term of the program in the same year. The second batch of Campus Teaching is expected to recruit 17,000 students who would be deployed to 3,400 designated elementary schools and 3,000 students will be deployed to 375 junior high schools in 34 provinces throughout Indonesia. The targets of the second term of the program are Elementary Schools (SD) and Junior High Schools (SMP) in underdeveloped, remote, and underprivileged and/or schools with $\mathrm{C}$ accreditation (or B accreditation with low score). This program recognizes the conversion of learning outcomes of up to 20 credits per semester as well as a reduction in tuition fees of up to IDR 2.4 million and a monthly allowance.

The Campus Teaching program has four important points, namely continuing learning activities during the pandemic, especially for elementary and junior high schools in the underdeveloped and remote area, presenting students as part of strengthening literacy and numeracy learning, and being teacher partners in creativity and innovation in learning by integrating information and technology. In addition, students may also contribute to supporting school principals to make school administrative and managerial efficiency. This is in accordance with the Freedom Campus policy which allows students to study outside campus for up to 2 semesters or equals to 40 credits, but still relevant with their expertise.

In addition, universities benefit from the program by achieving points in terms of IKU, especially at indicator point number 2 that the students have learning experiences outside the main campus (home campus) and the lecturers are involved as site supervisors to support the achievement of university's primary indicators of performance. The $2^{\text {nd }}$ batch of Campus Teaching program is open to 4,700 higher education institutions under the coordination of Directorate General of Higher Education (Ditjen Dikti) and is open to all study programs, undergraduate, and applied undergraduate, both from education and non-education backgrounds. The requirements for the Campus Teaching for students are students at least they are in semester 5. The target of the $2^{\text {nd }}$ batch of Campus Teaching is both elementary schools and junior high schools with $\mathrm{C}$ accreditation and located in Papua, West Papua, Maluku, and East Nusa Tenggara, as these schools' accreditation needs to be improved.

\subsubsection{Research Assistantship}

For students whose passion is being researchers, the Independent Learning program accommodates the students with an academic program in the form of research activities at research institutions or study centers. Through research, students may develop critical thinking - something that is very much needed for various scientific groups at the higher education level. With the ability to think critically, students are expected to explore, understand, and be able to do research methods better. For students who have an interest and desire to work in the research field, the opportunity to do an internship in a research center laboratory is their dream. In addition, laboratories or research institutes sometimes lack research assistants when working on short-term research projects ( 1 semester to 1 year).

The purposes of the research assistantship or internship are as follows: 
- The quality of student research is expected to be improved. In addition, students' experience in large research projects strengthens the research talent pool topically.

- Students gain research competence through direct mentoring by professional or full-time researchers at research institutes/study centers.

- Improving the academic environment and the quality of research in Indonesian laboratories and research institutions by providing research resources and regeneration of researchers from an early age.

For the mechanisms of applying the research assistantship are as follows:

- Universities should make an agreement in the form of a partnership document (MOU or MOA) with relevant partners from research institutes/research laboratories.

- Students have rights to participate in the selection and evaluation of research programs at research institutes/laboratories outside the campus.

- Appoint supervising lecturers to provide guidance, supervision, and together with researchers in research institutes/laboratories to provide grades.

- Lecturers together with researchers compile a logbook form and conduct final evaluation and equalization of research activities in institutions/laboratory into relevant courses (credits) as well as sustainable programs.

- Develop technical guidelines for learning activities through research.

- Report the results of learning activities to the Directorate General of Higher Education through the Higher Education Database.

Partners together with teaching assistants evaluate and assess research projects carried out by the students. For students who are doing research internships, what needs to be done are as follows:

- All Independent Learning requires students to earn permission from the Academic Advisor (DPA); it should be clear that the students register for the research assistant program.

- Carry out research activities in accordance with the direction of the research institutes/study center where the research is conducted.

- Fill out the logbook according to the activities carried out and prepare activity reports and submit reports in the form of research reports/thesis or scientific publications.

\subsubsection{Student Mobility}

Currently, student exchanges or student mobility with full credit transfers have been carried out with partner domestic universities and abroad. However, the credit transfer system carried out between universities in the country itself is still very small in number. This allows universities to remap the pattern of student collaboration and exchange in order to accommodate academic and administrative needs. Student exchanges are held to shape several student's attitudes as stipulated in the Regulation of the Minister of Education and Culture (Permendikbud) Number 3 of 2020, namely respecting cultural diversity, views, religions, and beliefs, as well as other people's genuine opinions or findings; and work together and have social sensitivity and concern for society and the environment.

Through the student mobility program, it is expected that the university benefits as follows:

- Studying across campuses (domestic and overseas) and living together with family at the destination campus may stimulate the character building and tolerance as of Bhinneka Tunggal $I \mathrm{ka}$ and cross-cultural and ethnic brotherhood are stronger.

- Building student's friendships between regions, ethnicities, cultures, and religions, thereby increasing the spirit of national unity and integrity.

- Organizing the transfer of knowledge to cover educational disparities between domestic universities, as well as the condition of higher education in the country and abroad.

Some learning activities that can be carried out within the framework of an academic mobility are such as student exchange between study programs at the same university (internal mobility). The form of learning that can be taken by students to support the fulfillment of learning outcomes, both those already stated in the curriculum structure of the study program and curriculum development to enrich the learning outcomes of graduates, can be in the form of elective courses.

The implementation mechanism starts from each study program, namely by compiling or adjusting a curriculum that facilitates students' needs to take courses in other study programs. Respective study programs determine and offer courses that students may take from outside the study program. Regulating the quota of participants who take courses offered in the form of learning in other study programs at the same university. 
Lastly, set the number of credits that can be taken from other study programs.

For students, the things that must be done is to gain the approval of the Academic Advisor (DPA) so that the program they follow is in accordance with the objectives and graduate attributes of the study program. Students should participate in activities outside the study program in accordance with the provisions of existing academic guidelines. Learning activities in other study programs (host campus) at the same university (internal student mobility) have collaborated, which can be done face-toface or online.

In terms of student exchange in the same study program at different universities, the form of learning that students may attend is to enrich the experience and scientific context obtained at other universities that have specific characteristics or learning support vehicles to optimize graduate learning outcomes (CPL). Slightly different from internal mobility, cross-university exchanges should be preceded by compiling or adjusting a curriculum that facilitates students to take courses in the same study program at other universities. Both study programs are required to make an agreement with partner universities, including the learning process, semester credit recognition and assessment, and financing schemes. Cooperation can be done in the form of bilateral, consortium (study study association), cluster (based on accreditation), or zoning (based on region).

Several things need to become concerns in regulating student quotas and distribution, namely regulating the quota of participants (inbound and outbound students) who take courses offered in the form of learning in the same study program at other universities; regulate the number of courses that can be taken from the same study program at other universities; and reporting activities to the Higher Education Database.

Learning activities in the same study program at different universities can be done fin-person or online learning. Learning that is carried out online with the provisions of the courses offered should receive recognition from the Ministry of Education and Culture. The forms of learning that can be taken by students at different universities to support the fulfillment of learning outcomes, both those already contained in the curriculum structure of the study program, as well as curriculum development to enrich the learning outcomes of graduates.

\subsubsection{Independent Study and Certified Internship Programs}

The Certified Independent Study and Internship Program (MSIB) is one of the learning programs by the government, of the eight methods proclaimed in the
Independent Learning policy. In addition to the MSIB program, other programs are implementing community service projects in villages, teaching in educational units, participating in student exchanges, conducting research, conducting entrepreneurial activities, making independent studies/projects, and participating in humanitarian programs. The policy was launched in order to prepare our students to face the changes and dynamics of social, cultural, world of work, and rapid technological advances, student competencies should be prepared to be more relevant with the needs of the times. Link and match not only with the world of industry and the world of work, but also with a rapidly-changing trend.

For the MSIB program, so far students have lacked work experience in the real industry/professional world so they are not ready for work. Meanwhile, short-term internships (less than 6 months) are considered as not sufficient to provide students with industrial experience and competence. Companies that accept internship students also state that internships for a very short time are very less useful, even disrupting activities in the Industry. The MSIB program is a maximum of 2 semesters, providing sufficient experience for students, direct learning in the workplace (experiential learning). During the program, students are expected to gain hard skills like complex problem-solving, analytical skills, etc. and soft skills, e.g. professional/work ethics, communication, collaboration, etc. Meanwhile, the industrial sector may get potential talents who, if suitable, can be recruited immediately, thereby reducing the cost of recruitment and initial/induction training. Students who are familiar with the workplace will be more confident in entering the world of work and careers.

Through this activity, issues in the industrial sector are transferred to universities so that updating teaching and learning materials for lecturers and research topics in universities to be more relevant with the industrial sector and job market. It is believed that this is a major change that requires a lot of adjustment. Especially for universities and lecturers, there are many challenges and problems. For this reason, the Directorate of Learning and Student Affairs provides direction to universities and lecturers so that they may utilize the MSIB program as a success by providing convenience and recommendations for students to participate directly.

\subsection{University's Strategies to Accommodate Independent Learning}

In implementing the Independent Learning programs, Unesa has implemented several strategies and issued policies, including forming the Center for MB-KM under the coordination of the Office of Academic Affairs. This center specifically accommodates the management of activities related to the MB-KM Curriculum, which 
includes three main aspects, namely community service, student exchange/mobility, and teaching practices and industrial internships.

With its central position and role, the Center for MB$\mathrm{KM}$ is expected to propose the obligations, tasks and functions of each division in this work unit. Among them are compiling duties, authorities, and procedures in services and assistance in work units. Furthermore, the divisions manage activities by designing an information system specifically for the MB-KM program that is integrated with the academic system at Unesa and the university's strategic plan to meet the Primary Indicators of Performance (KPI) of higher education.

\subsection{Coda: Reflection on Independent Learning}

In this section, several challenges, obstacles, and opportunities for the development of the Independent Learning and Freedom Campus programs are addressed since the program was launched by the Ministry of Education and Culture in 2019 until 2021. First issue is that all activities run at the same time, making it difficult for universities to accommodate students' needs and meet the procedures set by the government, while existing programs are actually still transitional. In addition, the government is still experiencing problems as evidenced by the MB-KM system/account not being able to accommodate a large number of participants who register almost at the same time. As a result, the list of students is not stable as well as the lecturers involved.

The pattern of the activities has not yet been determined uniformly, namely in the form of on-site activities or online. This may very well depend on the conditions of the pandemic. In 2021, the activities were carried out in accordance with the conditions of social restrictions in the respective regions. Students finally develop mutual jealousy between online and in-person activities. In the end, it was the online host campuses that were blamed by the students.

In addition, there will be more funds in 2021 due to assistance from the Indonesian Endowment Fund for Education (LPDP). However, the disbursement process which was complicated and could not be given simultaneously raised many questions from the students and lecturers regarding the transparency of this program's financial management. The existence of LPDP is a new opportunity for the program development and transparency of implementation.

Lastly, the most basic thing that can be done as an effort to optimize the programs is with comprehensive preparation and socialization. Several other issues that have not been accommodated are the status of public and private universities that may apply different university's policies, especially in terms of financial management and academic calendars. Student exchanges in 2021 between private and state universities, for example, still require a longer synchronization process.

\section{CONCLUSION}

Since it was initiated in 2019 by the Ministry of Education and Culture, the MB-KM program has become a new trend in higher education policy in Indonesia. In its implementation, the Independent Learning programs gave universities the flexibility to implement it in the form of an independent institution program. In addition, the government through the relevant ministries also accommodate the Independent Learning programs through several activities, including Campus Teaching, Research Internships, Student Mobility, and Independent Study and Certified Internship Programs, and community services. In its implementation, there have been some issues that require adjustments in both policies and strategies.

The programs proposed by the government require good management within universities to optimize the implementation of the policies and programs, providing guarantees for the students to gain their rights to be able to study and participate in academic activities outside the main campus. Some of the strategic policies carried out by the university include the formation of a special work unit that handles the Independent Learning program and compile the main tasks of implementation in the form of a Rectorate Decree and White Paper concerning the MBKM Curriculum, conversion guidelines, and curriculum structure. In addition, the university has developed a special integrated information system for the MB-KM program named MELISA through Academic Integrated System (SIAKADU) which is integrated with the primary indicators (IKU). Considering that it is currently still in the transition period for the implementation of the Independent Learning programs, two years since its inauguration, adjustments and evaluations are needed. Several studies and indicators of achievement are also needed in order to optimize program implementation.

\section{AUTHORS' CONTRIBUTIONS}

We conceived and designed this study and contributed to the process of revising the manuscript. The authors act and are assigned as the senior staff and senior advisors for academic affairs at the Office of Academic Affairs of the university. At the end, the authors have approved the final version of this manuscript. 


\section{ACKNOWLEDGMENTS}

We extend our gratitude to the University for the grant through the university's strategic policy research scheme 2021 in regards with the implementation of the Independent Learning program. In addition, we thank Postgraduate, Universitas Negeri Surabaya, for having accommodated a design research forum through the STEACH International Conference 2021.

\section{REFERENCES}

[1] Kemendikbud, Buku Saku Utama Altivitas Mahasiswa: Kampus Mengajar 2021, Kementerian Pendidikan dan Kebudayaan, 2021.

[2] Kemendikbud, Panduan Penyusunan Kurikulum Pendidikan Tinggi Di Era Industri 4.0 Untuk Mendukung Merdeka Belajar-Kampus Merdeka. Direktorat Jenderal Pendidikan, 2020.

[3] A. Widiyono, S. Irfana, K. Firdausia, Implementasi Merdeka Belajar Melalui Kampus Mengajar Perintis Di Sekolah Dasar. Metodik Didaktik: Jurnal Pendidikan Ke-SD-an, 2021. 16(2): p. 102-107.

[4] Kemendikbud, Buku Panduan Indikator Kinerja Utama PTN, Dirjen Pendidikan Tinggi, 2020.

[5] Unesa, Rencana Peralihan Universitas Negeri Surabaya Menuju PTN BH. Universitas Negeri Surabaya, 2021

[6] Unesa, Laporan Evaluasi Diri Universitas Negeri Surabaya, Universitas Negeri Surabaya, 2021.

[7] B. Yulianto, et al., Pengembangan Kurikulum Merdeka Belajar-Kampus Merdeka Universitas Negeri Surabaya. 2020, LP2M Universitas Negeri Surabaya: Surabaya. p. 1-36.

[8] Unesa, Laporan Evaluasi Diri Universitas Negeri Surabaya Tahun 2021, Universitas Negeri Surabaya, 2021.

[10] H, T., et al., The Implementation of Blended Learning Model to Learning Independence and Learning Outcomes of Vocational Students, 2021.

[11] N. Siregar, R. Sahirah, A.A. Harahap, Konsep Kampus Merdeka Belajar Di Era Revolusi Industri 4.0. Fitrah: Journal of Islamic Education, 1(1), 2020, p. 141-157.

[12] M. Basri, et al., School Mapping to Support the Implementation an Independent LearningIndependent Campus Program in West Lampung Regency. International Journal of Multicultural and Multireligious Understanding, 8(3), 2021, 164.

[13] Pezalla, A.E., J. Pettigrew, and M. Miller-Day, Researching the researcher-as-instrument: an exercise in interviewer self-reflexivity. Qual Res, 12(2), 2012 165-185.

[14] S. Jamieson, Analyse qualitative data. Education for Primary Care, 27(5), 2016, 398-402. 